\title{
Anachronism and the rewriting of history: the South Africa case
}

\author{
GEORGI VERBEECK
}

\begin{abstract}
The use and abuse of anachronism is often seen as the quintessence of the writing of history. Historians tend to conceive it as the hardcore of their métier to avoid anachronism. It designates a confusion in order of time, especially the mistake of placing an event, attitude, or circumstance too early. The awareness of historical anachronism is omnipresent in times of a radical rewriting of history, in particular as a result of political transformation. History reflects the needs and ambitions of a political context, and the sense of what is deemed historically significant does not remain unattached hereby. Chronology and anachronism are essential to particular conceptions of history, and if history is in a process of being rewritten, they are the first items to be addressed by the defenders of the old system and the advocates of a new discourse. In political debates on the use or abuse of history anachronism is often seen as ultimate proof of the (un-)reliability of new insights and conceptions. As anachronism is defined as a way of transferring contemporary sets of values, assumptions and interpretative categories, every political reorientation inevitably provokes a discussion on that level. If a 'new nation' is in search of a 'new past', a new reflection on the basic categories of historical thinking becomes necessary. The changing discourses in South African historiography since the end of Apartheid serve here as an illuminative example.
\end{abstract}

Keywords: Anachronism, historiography, Afrikaner nationalism, South Africa, philosophy of history, apartheid.

\section{Anachronism}

The use and abuse of anachronism is often seen as the quintessence of the writing of history. Historians tend to conceive it as the hardcore of their métier to avoid anachronism. It designates confusion in order of time, especially the mistake of placing an event, attitude, or circumstance too early. ${ }^{1}$ In the historical sciences the problem arises most significantly in the guise of so-called 'presentism' or 'presentmindedness', the impropriety of depicting past phenomena in terms of values, assumptions, or interpretative categories of today. Avoiding anachronism is seen as a reflection of extended awareness that the

* Georgi Verbeeck is an associate professor in history and currently associated researcher at the Department of Historical and Heritage Studies at the University of Pretoria. Address: Georgi.Verbeeck@history.unimaas.nl.

1 For a concise introduction, see: H Ritter, 'Anachronism', - in : DR Woolf (ed.), A Global Encyclopedia of Historical Writing, 1, (New York - London: Garland Publishing, 1998), pp. 30-31. 
past may differ fundamentally from the present - that the "past is a foreign country'. ${ }^{2}$ This awareness is considered a defining feature of advanced modern historical consciousness.

The reflection on the use or abuse of anachronism in history is closely linked to the rise of the doctrine of historical 'individuality' since early nineteenth century scholarship, in particular the notion that historical phenomena are to be understood according to their unique, time-andplace-specific principles or origin and development. ${ }^{3}$ It became the central paradigm of the tradition of German Historismus - better known as 'historicism' in the Anglophone world - to avoid anachronism by establishing 'empathy' with the past through immersion in historical sources. Historicism developed itself into a general science and method of analyzing all social and cultural phenomena. It starts from the assumption that an adequate understanding of the nature of any phenomenon and an adequate assessment of its value are to be gained through considering it in terms of the place which it occupied and the role it played within a process of development. According to the historicist doctrine, all phenomena are unfolding, developing processes whose ends are encoded in, and explained, by their origins.

Methodologically the doctrine of historicism is based on the notion that all phenomena, both contemporary and past, should be understood by means of interpretation from within (Verstehen). Historical facts, figures and developments should be analysed within the framework of their own values and intentions. On an epistemological level, much discussion of historicism is of its relativistic repercussions. If all knowledge and values are relative to their historical context, absolute and universal values tend to become untenable. This was what leading intellectuals perceived as an inevitable 'crisis of historicism', along with a deep crisis of modernity in European culture around the beginning of the twentieth century (Ernst Troeltsch). ${ }^{4}$

The topic of anachronism was also discussed at length by historians of what came to be known as the French Annales school to express philosophical doubts about the practice of history as an exact science. Reconsiderations of the historian's 'sin of sins', as Lucien Febvre referred to anachronism in 1942, were initially framed by Marc Bloch and Febvre, who worried about historians projecting their mental 'equipment [outillage]' onto other eras. The influential concepts of mentalité and longue durée emerged in response to the question of how, if ever, the past is objectively portrayed,

2 "They do things different there. Isn't that what they say?" See D Lowenthal, The Past is a Foreign Country, (Cambridge: University Press, 1985).

3 For a concise introduction, see A. Tucker, 'Historicism' in DR Woolf (ed.), A Global Encyclopedia of Historical Writing, 1, pp. 414-415.

4 Still the best introduction to the subject is GG Iggers, The German Conception of History: The National Tradition of Historical Thought from Herder to the Present, (Middletown: Wesleyan University Press, 1968.) 
given that historians necessarily approach the past from the present, anachronistically, "like a movie reel that is unwound in the opposite direction from which it is viewed.' In other parts of Europe, most famously in Frankfurt, where another 'school' was simultaneously forming, similar discussions of the contingency of historical truth developed on the same Marxist foundation. ${ }^{5}$

The most sophisticated theoretical model of 'anachronism' conceived as a term operating in opposition to 'chronism' is undoubtedly Walter Benjamin's notion of the dialectical image'. ${ }^{6}$ Post-modernist thinking about the conception of time and anachronism is largely indebted to Walter Benjamin's famous philosophy of the arts. According to Benjamin the mechanical reproduction of the work of art had created 'alienation' between the authenticity of an original piece of art and the reproduction of its copies. Since the late 1970s the old tradition of historicism became revitalised by means of a radical redefinition of its basic premises. The New Historicism arose as a by-product of post-modernism. Discourses are no longer seen as expressions of unchanging, permanent and universal truths, but as parts of networks of intertwining literary and non-literary texts that constitute the outskirts of a particular culture. ${ }^{7}$

Post-modernist theories have put the problem of anachronism on the agenda of a wide variety of cultural and social sciences, such as the arts and literature, science, medicine and technology. It is a current issue in the history of the fine arts and fiction. The public at large will generally tend to view anachronism as an offence or mistake. Yet modern artistic productions will still rely on anachronism for special effects, such as disenchantment, irony or social critique. The issue of anachronism is also discussed in the realm of the hard sciences. Even historians of science and technology argue that:

\footnotetext{
Anachronism is a useful heuristic tool. Without it, you cannot perceive, you don't have the intellectual categories to understand people who lived in the past. You have to be anachronistic in order to avoid the fallacy that scientific facts take on the semblance of naturalness. Without it, the historian would be complicit in the social technologies of modernization. ${ }^{8}$
}

The tradition of historicism had undoubtedly led to a greater awareness of the limits and validity of historical consciousness. The ascription of contemporary categories and models of interpretation to earlier periods of time is now regularly regarded as a violation of the past's alien integrity. The classical historicist position of 'sympathy' with the past - l'histoire pour l'histoire - is hardly tenable anymore, as historians are all too much

5 JA Winders, European Culture Since 1848: From Modern to Postmodern and Beyond, (New York: Palgrave, 2001), pp. 219-224.

6 C Farago, 'Response: Time Out of Joint' in The Art Bulletin, 1 September 2005.

7 For a concise overview see P Budra, 'New Historicism' in DR Woolf (ed.), A Global Encyclopedia of Historical Writing, 2, pp. 656-657.

8 Interview with German historian of the human body Barbara Duden by Frank Huisman, University of Maastricht, 11 February 2004. 
aware of the present-centered starting point of their knowledge and investigation. Historians are too much aware of the fact that they, while inevitably belonging to some present, in the mere act of conceiving and constituting their research, cannot avoid imposing present categories on the past in some degree. ${ }^{9}$ The various discussions on historicism and its implication teach us however that the problem of anachronism, whether perceived as a major error or as an unavoidable category, touches the essence of the writing and dealing with history.

Lorenz, a Dutch historian and philosopher of history, argues that anachronism is closely connected to the emergence of historical consciousness in Western history. ${ }^{10}$ The rise of historical consciousness - the growing awareness that the past can never be reduced to a reverse attachment of the present and is therefore essentially 'alien' - made an anachronistic approach to history possible. ${ }^{11}$ In pre-modern societies history was merely conceived as a step in a continuous chain linking the past, the present and the future to each other. The past is seen as 'tradition', where our forefathers act as contemporary companions. The past has a normative function, as far as it regulates the norms and values of the present. According to Nietzsche, 'the dead dictate the lives of contemporary people'. Since the emergence of historical consciousness, the past is no longer seen a chronological chapter antedating the present, but as an imminent process of development and change. What belongs to the past is therefore essentially different from the here and now. The old adage Historia magistra vitae became obsolete since then. History can never truly 'teach lessons' for the present. Anachronism is not only a mere by-product of the new attitude towards the past; it becomes an inevitable consequence of the writing of history as such. Since history is change per se, looking back to the past intrinsically occurs through the perspective of nowadays. ${ }^{12}$

To avoid further complication in the use of the concept, Lorenz suggests that it is necessary to distinguish between three basic forms of anachronism: 1. 'anachronism of facts'; 2. 'anachronism of language'; 3. 'anachronism of perspective'. ${ }^{13}$ Factual anachronism consists of facts, knowledge or ideas that are out of their natural time, or at least appear to be. This kind of anachronism is generally seen as a capital crime for the writing of history. Anachronism of language occurs when historians

9 H Ritter, 'Anachronism', - in : DR Woolf (ed.), A Global Encyclopedia of Historical Writing, 1, p. 30.

$10 \mathrm{C}$ Lorenz, De constructie van het verleden. Een inleiding in de theorie van de geschiedenis, (Amsterdam - Meppel: Boom, 1998), pp. 247-249.

11 See also : J Rüsen, Historische Vernunft. Grundzüge einer Historik. I: Die Grundlagen der Geschichtswissenschaft, (Göttingen: Vandenhoeck \& Ruprecht, 1983), pp. 68-75.

12 I refer to the work of another Dutch historian: P Blaas, Anachronisme en historisch besef. Momenten uit de ontwikkeling van het Europees historisch bewustzijn, (Den Haag: Nijgh \& Van Ditmar, 1988), pp. 1-32.

$13 \mathrm{C}$ Lorenz, De constructie van het verleden. Een inleiding in de theorie van de geschiedenis, pp. 248-249. 
use contemporary vocabulary in order to describe and understand past phenomena. Historians, notwithstanding their often articulated intention to avoid their personal and contemporary perspective, will find it hard, if not impossible, to avoid this kind of anachronism. The third variation implies a more fundamental problem. Historians use interpretative frameworks that stem from their own contemporary position, and not from the past itself. The use of modern theories in order to understand the past serves as an example of this enterprise. Historians are finally placed in an absolutely unique position that distinguishes them from the past as their study object. Historians are the observers of processes and events that have come to an end. They have the privilege to better understand the past than the historic actors themselves. History, conceived as a process that has a starting point and an end, can only truly be understood by transcending history and therefore by looking at it anachronistically.

\section{Rewriting history}

The awareness of historical anachronism is omnipresent in times of a radical rewriting of history, in particular as a result of political transformation. ${ }^{14}$ History reflects the needs and ambitions of a political context, and the sense of what is deemed historically significant does not remain unattached hereby. ${ }^{15}$ Chronology and anachronism are essential to particular conceptions of history, and if history is in a process of being rewritten, they are the first items to be addressed by the defenders of the old system and the advocates of a new discourse. In political debates on the use or abuse of history, anachronism is often seen as ultimate proof of the (un-)reliability of new insights and conceptions. As anachronism is defined as a way of transferring contemporary sets of values, assumptions and interpretative categories, every political reorientation inevitably provokes a discussion on that level. If a 'new nation' is in search of a 'new past', a new reflection on the basic categories of historical thinking becomes necessary. The changing discourses in South African historiography since the end of Apartheid serve here as an illuminative example. ${ }^{16}$

The end of apartheid urged the need for a radical renewal of South African historiography. ${ }^{17}$ The central aim was the promotion of crossracial reconciliation by creating a new sense of national identity and

14 S Berger, The Search for Normality. National Identity and Historical Consciousness in Germany since 1800, (New York - Oxford: Berghahn Books, 2002) pp. 1-20.

15 E Foner, Who owns the Past? Rethinking the Past in a Changing World (New York: Hill and Wang), 2002), p. ix.

16 G Verbeeck, 'Een nieuw verleden voor en nieuwe natie. Een Duits model voor ZuidAfrika' in J Tollebeek, G Verbeeck and T Verschaffel (eds.), De lectuur van het verleden. Opstellen over de geschiedenis van de geschiedschrijving aangeboden aan Reginald de Schryver (Leuven: University Press, 1998), pp. 535-563.

17 See for instance S Jeppie (ed.), Toward New Histories for South Africa. On The Place Of The Past In Our Present, (Lansdowne: Juta Gariep, 2005). 
consensus. The writing of history plays an important role herein. History should serve as a mirror for cooperation, interaction and peaceful coexistence of different social and cultural groups, not as an interpretative framework for racial essentialism and 'differentialism'. ${ }^{18}$ According to the newly established dominant ideology, a common history should serve as a model for the common future. But this call was not entirely new in the history of South African historical writing. The changes in South African historiography do not quite coincide with the political caesura of 1994. The search for an image of history, better suited to the reality of a multi-racial democracy brought about by the regime change, could be linked without much effort to the process of renewal set in motion during the seventies and eighties. The historical myths on which the apartheid regime was founded may survive in vulgarised surveys, but the latter were shown up for what they were by new insights into the science of history long before 1994. Gradually a 'national image of history' came into being which included different social and cultural population groups (blacks, coloureds, and other ethnic minorities, but also women, farm labourers, migrants, ordinary people in general), an image at variance with apartheid thought. Since the dismantling of the apartheid regime, recommendations on how to develop an image of history better suited to the new social and political relations have been pouring in from all sides. The blueprints for a new curriculum contain two components: critical and alternative, in other words a demand to settle accounts with the old image of history and a call to formulate a new vision of history. What then are the ingredients for this 'New History for a New South Africa'? ${ }^{19}$ It will be argued here that a new history for a new SA will have to deal substantially with the problem of anachronism.

\section{Deconstructing old narratives}

The central aim of a new conception of history that tries to fit into a new political and cultural discourse is the deconstruction of traditional images of history, of representations and interpretations which legitimized the former colonial community and the old white oligarchy. ${ }^{20}$ Colonial and apartheid historiography was based on a strongly mythologized representation of the arrival of whites on the African continent and the conflict with the different population groups in the interior. Within the contemporary political perspective it is no longer tenable to have

18 AE Coombes, History after Apartheid: Visual Culture and Public Memory in a Democratic South Africa (Durham - London: Duke University Press, 2003.)

19 J Bam and P Visser, A New History for a New South Africa (Cape Town: Kagiso, 1996).

20 This section draws especially from: J Bam and P Visser, A New History for a New South Africa, pp. 33-57. Also refer to: M Cornevin, Apartheid. Power and Historical Falsification (Paris: Unesco, 1980); J Naidoo, Tracking Down Historical Myths (Johannesburg: Ad. Donker, 1989). 
stereotypes up to the present which in some cases are maintained and propagated by the mass tourism business, such as:

1. the view that Europeans and Bantu peoples arrived 'simultaneously' in southern Africa, in order to make the viewpoint acceptable that both are involved in a more or less equal battle for survival;

2. Rousseauistic representations of an 'uncivilized', but at the same time also a 'pastoral, idyllic', 'authentic' and 'unspoiled' Africa, where indigenous peoples live happily and in harmony with nature;

3. and especially the application of a particular type of 'psychology of nations' in order to promote stereotypical characteristics of 'Zulus', 'Xhosas', 'Tswanas', 'Ndebeles', 'Coloureds', etc.

In the new ideology of history, aimed at national reconciliation, there is no more room for similar myths from old textbooks, rather for faith in a better and brighter future.

One can certainly not underestimate the gradual and profound change that even the academic Afrikaner historiography had undergone since the seventies and eighties - long before the official end of apartheid. ${ }^{21}$ Afrikaner historians themselves played a role in the gradual demythologizing of old nationalistic sagas. There have been substantial efforts to bring about new perspectives and methodologies in the writing of the history of the various peoples in South Africa. Particularly F. A. van Jaarsveld has constantly addressed the issue of 'responsibility' and historical consciousness. ${ }^{22}$ Interesting historical controversies were taking place in the eighties, a time during which South Africa underwent dramatic political development, reflecting the precarious position of many Afrikaner historians finding themselves at a major junction. Nothing less than the long-term future of the white culture in South Africa, and its growing isolation from other groups as well as from the international community was at stake. The process of historiographical differentiation, as well as a growing awareness of historical guilt and responsibility was the necessary by-product of a deeper crisis of Afrikaner nationalism and its essential paradigms. ${ }^{23}$ Central target of post-1994 criticism was not so much academic Afrikaner historical writing, but merely the underlying ideological assumptions as well as what has been labelled the 'school

21 A recent (personal) reflection on the transformation process of contemporary historical writing, including the theoretical reflection on history in the Afrikaner academic community can be found in $\mathrm{H}$ van Aswegen and $\mathrm{P}$ Kapp, Verandering en vernuwing in geskiedsbeskouing. ' $n$ Gesprek oor die ervaringe van twee tydgenote (Kleio : Pretoria, Stellenbosch, Vanderbijlpark, 2006.)

22 Seein particularFAvanJaarsveld, Omstrede Suid-Afrikaanseverlede. Geskiedenisideologie en die historiese skulduraagstuk (Johannesburg - Cape Town: Perskor, 1984).

23 K Smith, The Changing Past. Trends in South African Historical Writing (Southern Book Publishers : Johannesburg, 1988), pp. 89-102. 
book version' of South African history dominated by a white European perspective. $^{\mathbf{2 4}}$

It is an established fact that Afrikaner nationalism is supported by a comprehensive, historical, heroic saga. ${ }^{25}$ Especially the central tale of the Great Trek from the Cape Province around 1835 as foundation myth of an independent Boer nation occupies such a prominent position. In the next political context this event is now seen as one of the numerous streams of migration within a whole made up of different transformation processes, from which the foundation date of one separate nation can only be deduced with difficulty. The Trek to the North, itself being part of complex migration movements, cannot be placed at the 'beginning' of the Afrikaner nation, as being accepted for a long time. The story of the Great Trek and the message of salvation of the Chosen People became fashionable much later. ${ }^{26}$ Nationalistic Afrikaners construct their own historical, political Sonderweg. Inevitably, blacks disappear from the broader historical perspective dominated by whites, unless when portrayed as enemies and opponents on one of the countless battlefields. The South African example shows that the process of nation-building should rather be described as an element of political decision-making than in terms of evolutionary development. ${ }^{27}$ According to the new post-modernist paradigm, a nation does not 'grow' according to natural laws, but is rather the effect of an ideologically motivated 'construction'. In the case of South Africa this brings to the conclusion that deconstruction of the old national master narrative leads to the construction of a new one. Both are constructions inspired by a political agenda, and therefore thoroughly 'anachronistic'. In South Africa the old concept of nation building under apartheid was essentially based on the principles of ethnic pluralism (or separatism). The new paradigm of nation building since 1994, however, is inspired by the idea of multiculturalism (or togetherness).

The Great Trek as foundation myth of white South Africa links up with the representation of an 'empty interior' as a result of bloody tribal disputes amongst black African communities. Especially the Zulu expansion under king Shaka (Mfecane or Difaqane) belongs to one of the episodes of South African history which most captures the imagination. The rising of the Zulu kingdom and its territorial expansion and the following forced removal of other groups is a strongly contested issue amongst historians. Now it is no longer only the bellicose spirit and the expansionist urge of the martial

24 See also: C Saunders, The Making of the South African Past. Major historians on race and class (David Philip: Johannesburg - Cape Town, 1988), pp.186-191.

25 L Thompson, The Political Mythology of Apartheid, (London - New Haven: Yale University Press, 1985), pp. 25-68.

26 H Giliomee, "Constructing Afrikaner Nationalism", in Journal of Asian and African Studies, 18 (1983), pp. 83-98.

27 See the different contributions in: S Marks and S Trapido (eds.), The Politics of Race, Class and Nationalism in Twentieth Century South Africa (London- New York : Longman, 1987). 
Zulu's which is highlighted, but matters of a social and economic nature are also taken into account: drought, conflicts concerning the ownership of farm land, control over commercial routes. The view of a 'depopulated interior', used by European colonists to support their regional claims, is no longer accepted, in the light of the presence of indigenous population groups.

An analogous debate can be held about the adventures of the legendary Trek-leader Piet Retief who, along with his companions, was murdered after negotiations with Zulu chief Dingane about property rights in Natal, later to be avenged in the famous battle of Blood River (1838). He can no longer be seen as a brave hero, killed in cowardly fashion, but as a representative of the white thirst for expansionism. Does the 'treaty' between Retief and Dingane, which would have supported the first territorial claims and white appropriation of Natal exist, as was maintained for a long time by white South Africa? Once again efforts are being made to refute the arguments and the old historical claims of whites on black land.

In South Africa, as is the case almost everywhere else in the world, the remembrance of wars also offered many points of contact for national or group-bound identification. The 'Anglo-Boer War' is no different. Through its main characters - British imperialists versus Afrikaner nationalists - this war got the reputation of a 'White Man's War'. Once again black actors, whether active or passive participants, disappeared from the dominant perspective. It seems that the memory of that sharp conflict is not compatible with the new national consensus. According to a current tendency towards unity thinking there is no longer talk of 'victors' and 'victims'. Black auxiliary troops - on both sides of the front - must now get the deserved attention. Prompted by last year's centenary, the old 'Anglo Boer War' is being noiselessly rebaptised into a new 'South African war' - or into what is even more neutral: the '1899-1902 war'. As though within the new national community there is no longer room for a 'separate' commemoration of those who died, but only for a collective remembrance uniting the victims in a posthumous act of reconciliation. The collective commemoration of all the victims, irrespective of the racial or ethnic dividing line of old, must therefore serve the new national unity. ${ }^{28}$

\section{Political language}

Language is never politically neutral. Words have a political content. The cultural revolution which the new South Africa has experienced since the end of the apartheid regime, inevitably involves a revolution on the level

28 G Verbeeck, 'De Anglo-Boerenoorlog in een veranderend perspectief. Een comparatieve benadering' in Journal for Contemporary History, 2000, 25(2), pp. 284-310. 
of language use. ${ }^{29}$ Words and ideas on which apartheid had conferred the semblance of something evident, implicitly accepted as such even outside the system, was now exposed as a cover for social and political power relations. ${ }^{30}$ Sociolinguistics teaches us that words are never merely descriptive, only a portrayal of factual circumstances, but that they clarify the ideas and interest of the speaker. This is particularly true as far as the central vocabulary supporting the ideology of apartheid, inherited from a centuries-old practice of racial segregation, is concerned: 'whites', 'coloreds', 'blacks', 'Bantu', 'Africans', are all concepts which, according to the new norms of political correctness, may only still be used when combined with the necessary prefix 'so-called'.

For the same reasons, traditional concepts such as 'groups', 'ethnic groups' and 'population groups' are avoided in the new political context; in other words, exactly that set of terminological instruments which had supported and made apartheid legislation possible. It is no coincidence that the concepts all express a static character. They are now replaced by references to cultural or social 'traditions' which are dynamic by definition and also leave open the possibility of personal choices. ${ }^{31}$ The intention is to avoid especially those concepts which suggest the 'natural' status and therefore the invariable group homogeneity. After all, population groups are thus represented as internally homogeneous and one another's rivals. It is type of a language use which, through the use of different words, expresses the striving for ethnic separatism. At the same time, white monopoly of power is legalised: a common identity is ascribed to whites, irrespective of their origin, while blacks remain divided according to different ethnic groups. The old apartheid thought was completely 'essentialist' and 'differentialist' at the same time: it laid down the 'invariable' characteristics of population groups along with their respective differences, resulting in 'natural' rivalry. ${ }^{32}$ It goes without saying that a similar discourse can no longer be reconciled with the ideological paradigm upon which the new South Africa rests.

The new political vocabulary seeks to replace terms which originated in a colonial context with a more neutral description of concrete, linguistic or socio-economic realities: 'Bantu-speaking' peoples (instead of 'black Africans'), 'hunters-gatherers' (instead of 'Bushmen' or 'San') and 'stock farmers' (instead of 'Hottentots' of 'Khoikhoi') may serve as examples. From the same point of view, one no longer speaks about 'tribes' (with its accompanying social Darwinist and colonial undertones), but rather, one searches for a more adequate expression to convey the models of socio-

$29 \mathrm{~J}$ Bam and P Visser, A New History for a New South Africa, pp.128-153.

30 See eg.: E Boonzaaier and J Sharp (eds.), South African Keywords. The Uses and Abuses of Political Concepts (Cape Town: David Phillips, 1988).

31 TRH Davenport, South Africa. A Modern History (London 1994), p. 5.

32 J Degenaar, 'De mythe van de Zuidafrikaanse natie', in: R Detrez and J Blommaert (Eds.), Nationalisme. Kritische opstellen (Berchem: EPO, 1994), p. 331. 
political organization (chiefdoms). ${ }^{33}$ Added to that, it has become a rule to avoid especially concepts perceived as insulting by the parties concerned, such as 'Kaffirs', 'Hottentots', 'Bushmen', 'Coolies'. Even the term settler has become just as problematic for the new national ideology. Although, it initially had a neutral meaning for the parties concerned (descendants of Dutch and later British immigrants), radical pan-Africanists conferred the meaning of 'newcomer' on this concept, thus of someone without any historic 'rights' on South African soil. Radical pan-Africanism, which voiced itself in the bloodthirsty cry "One settler, one bullet" is a product of the same ideology of ethnic homogeneity. And this is no solution for a new multicultural South Africa either. In this way one prevents the white (Afrikaans- and English-speaking) communities from feeling themselves to be late arrival minorities because of the negative connotation of a settler, who is not permitted to participate fully in the national community. ${ }^{34}$

Any purification of language, however well-meant and necessary, may easily lead to cultural witch-hunt and to new forms of political dogmatism. If all language use becomes politically conditioned, the new banner of multiculturalism, of course, also conceals a politicized 'discourse'. A good example of this is found in the (in itself commendable) effort to avoid terms experienced by specific groups as insulting, and to give preference to descriptions used by the parties themselves. Thus, one could argue, everyone has a better guarantee of the right to (historical) selfidentification. But what happens when it turns out that 'San' ('Bushmen') is an expression borrowed from the language of the 'Koikhoi' ('Hottentots'), who have nothing but contempt for their neighbours and rivals? The 'Koikhoi' describe themselves in terms of universal humanity. As is the case with so many nations, they consider themselves to be "human beings' in the first instance; their neighbouring communities could be no less than primitive barbarians. In other words, must the xenophobia and the greatly exaggerated exclusiveness of the 'Koikhoi' become the norm for the new language use? For these reasons some prefer to restore the old term 'Bushmen'. This case can serve as a manipulative form of multiculturalism which effectively led to ethnic pluralism, but not to a new synthesis. ${ }^{35}$ The limited scope of the old eurocentrism is criticized, but at the same time replaced by a new ethnocentrism; in this case, that of the victims of the past.

The problem is more fundamental when the rejection of the languageuse that legitimizes ethnic 'differentialism' leads to the reflected social reality no longer being recognized as such. Terms and concepts which mirror the power relations within a colonial or racist society may well be morally or politically reprehensible, but in themselves form part of the

33 See also: P Maylam, A History of the African People of South Africa: from the Early Iron Age to the 1970s (London - Cape Town - Johannesburg 1995) pp. 64-68.

34 J Bam and P Visser, A New History for a New South Africa, pp. 146-148.

35 Ibid., pp. 131-134.

TD, 2 (1), July 2006, pp. 181-200 
social reality. Constructions about 'race', 'nation' or 'population groups' may not be a response to the 'natural' condition, but they nevertheless radically influenced the way people think, as well as their mutual relationships, and if only for that reason can therefore not be brushed aside as scientifically irrelevant. It is not because racist prejudices are no longer acceptable that their inner logic and especially their influence on social and cultural conceptions and conduct should no longer be suitable for further study. By merely replacing the old discourse with a new one, there is the danger of the disappearance of a large part of the historical and social world of experience. ${ }^{36}$

The same mechanism can be detected, for example, in the hesitation experienced by scholars of National Socialism who wish to study this ideology its own framework, and within the margins of its own logic. Because the (mostly veiled) nazi jargon as such generates such abhorrence with the present-day observer, one can easily escape into victim insiderism' - a group one can at least identify with. One adopts the point of view of what was experienced by the victims, as privileged spectators. But true insight into the mechanisms of power and suppression does not come that easily. The only way is to enter into the logic of power structures and of an ideology which, in the case of National Socialism, reduced the lives of others to lebensunwertes Leben. National Socialism and apartheid thought had at least one thing in common: both were ideologies with a compelling effect on reality: points of departure for action. ${ }^{37}$ "The secret of evil is locked up within the dynamics of the political ideas of the twentieth century." (François Furet) ${ }^{38}$

These examples clearly show that the political use of a new language is closely interrelated to the problem of anachronism. By introducing a new discourse which fits in a particular contemporary political context, the past's alien integrity is distorted. Motivations and dynamics of the past are exposed as an ideological façade. Anachronistic use of language may lead to the assumption that past generations were the victims of false consciousness, incapable of grasping reality as it should be perceived. It is exactly this pretension which lies at the heart of the totalitarian temptation.

36 Another example is the blotting out of ethnic differences through an exaggerated aversion to any kind of differentialism: the fusion of Khoikhoi and San to 'Koisan' or hunters-gatherers.

37 RA Pois, National Socialism and the Religion of Nature (London - Sydney: MacMillan, 1986) p. 22.

38 F Furet, Het verleden van een illusie. Essay over het communistische gedachtegoed in de twintigste eeuw (translated from the French.) (Amsterdam-Antwerp : Meulenhoff/ Kritak, 1996) 47. 


\section{Multiculturalism}

In the new South Africa, the paradigm of multiculturalism ${ }^{39}$ is clearly being projected onto history. Multiculturalism, taken as an alternative for the ethnic separatism of the apartheid system, is looking for a common image of history. ${ }^{40}$ Despite representing opposite poles, multiculturalism and ethnic pluralism are not always clearly distinguishable in practice and certainly not within the South African context. In its radical form of expression, the acknowledgement of cultural diversity may also lead to the slackening of universal moral values. Born from an intention of moral compensation, ethnic minorities will now demand a type of preferential treatment for their 'own' history. As compensation for past discrimination and injustice, minorities go in search of strong points of contact for a group-bound identity, resulting in a highly moral relativism. Thus ethnic pluralism becomes the precursor of ethnic separatism. ${ }^{41}$ Multiculturalism can only be a true alternative for ethnic separatism in so far as it places universal humane unity above the acknowledgement of cultural diversity. ${ }^{42}$ Multiculturalism and ethnic separatism differ when it comes to the question of what belongs to the essential characteristics of being human, and what is accessory.

What the advocates of multiculturalism have in mind in the first place, is to awaken the 'sense of a shared past'. ${ }^{43}$ This means that the emphasis is no longer laid on conflicts and opposition, but on a common world of experience. This is of course no easy assignment, taken the concrete historical experiences in South Africa, the endless series of bloody conflicts and wars in the past. The recent undertaking to shed new light on the 'South African war of 1899-1902' is such an example. But efforts are also being made to apply the same model of consensus on the countless clashes between the British and the Xhosas in the Eastern Cape, the so-called Frontier Wars of the nineteenth century. This can be done by emphasizing the fact that both the British immigrants and the indigenous population are locked in the same material and economic battle for survival and are mostly pursuing the same goals, namely ensuring their living conditions. Even the experiences and environment of population groups who live separately as far as language, culture and ethnicity are concerned, but who meet in a common social, economic work-place, can be placed in a new light: different groups of foreign contract labourers or indentured

39 Vele Kulture. Een Nasie. Inhuldiging van die President van Suid-Afrika 10 Mei 1994 (Pretoria 1994) pp. 28-33.

$40 \mathrm{~J}$ Bam and P Visser, A New History for a New South Africa, pp. 144.

41 Borrowed from examples within the American context: R Herzinger and H Stein, EndzeitPropheten oder Die Offensive der Antiwestler. Fundamentalismus, Antiamerikanismus und Neue Rechte (Hamburg: Rowohlt, 1995) pp. 110-116.

42 For this debate, consult: C Taylor, Multikulturalismus und die Politik der Anerkennung. Mit Kommentaren von Amy Gutman, Steven C. Rockefeller, Michael Walzer, Susan. Mit einem Beitrag von Jürgen Habermas (Frankfurt a.M.: Fischer, 1993).

43 J Bam and P Visser, A New History for a New South Africa, pp. 48-49.

TD, 2 (1), July 2006, pp. 181-200 
labourers' (Irish, Indians, Chinese), 'coloured' domestic servants and black slaves, independent and unfree Boers, and so forth. Instead of conflict and segregation, unavoidable interaction has to be emphasized. Certainly in the case of unfree labour and slavery - as in the American situation - a micro-approach can be the judge of the interwoven nature of relations between 'master' and 'slave' in a more nuanced way. Mixed relations and marriages break the pattern of official race separation. Is there a better way of showing up the inhuman aspects of racial segregation than the evocation of real lives of people from the past?

'Restoring Silenced Voices', bringing to life suppressed or silenced sounds from the past, is the aim of the new historiography in South Africa. Firstly, there are the victims of apartheid, who are removed from their traditional role as the oppressed and who previously almost exercised some influence on important developments in their country. It can thus be expected that a new history of heroes has been reserved for the ANC and for other resistance movements. As for other themes and 'forgotten groups', South African historiography finds its inspiration in the developments that have been part and parcel of Western historiography for a long time. Thus the history of women - more than the dismal destiny of the Boer women in the British concentration camps - the history of the working classes and of ethnic minorities (Jews, Chinese, East-Europeans, Portuguese) will be given a chance. Operation 'Restoring Silenced Voices' is the umpteenth instrument for constructing the experiences of people and groups now forming the network of the new South African identity. Bam and Visser argue:

We need a new historical synthesis now which seeks to represent the entirety of the South African historical experience. ${ }^{44}$

During the last few years, South African historiography has made a shift in emphasis which is also noticeable in other countries. With the rise of 'micro-history', interest for 'great men' is being transferred to the anonymous actors of history. A picture of the lives of ordinary people is being created - farm laborers, farmers, domestic servants. One example is Charles van Onselen's biography of Kas Maine, a poor black sharecropper on the South African Highveld in the twentieth century. ${ }^{45}$ The tales of ordinary lives serve as a kaleidoscope through which the impact of social and political changes can be viewed. The full significance of poverty, apartheid and persecution in people's lives can thus be measured in a more precise way. Another possibility of creating more of an interest in history with the broad public is sought in the writing of family histories or the conducting of local and regional history. Of course the danger lurking around the corner in such an enterprise is that of a new type of ethnic

44 Ibid., p. 36.

$45 \mathrm{C}$ van Onselen, The Seed is Mine. The Life of Kas Maine. A South African Sharecropper 1894-1985 (New York: Hill \& Wang, 1996). 
provincialism, which may mean that the link with the wider national context gets lost.

The new South African historiography wants to break with traditional eurocentrism and is looking for a new Africanist orientation. ${ }^{46}$ This means no longer being satisfied with textbooks limited to the history of Western Europe and North America, showing an interest in the rest of the world only in so far as it enters the western sphere of influence. The new, dominating ANC ideology is seeking contact with historical examples of 'national democratic revolutions' elsewhere in the world: decolonization of countries in Latin America, Africa, Asia and Oceania, the Chinese revolution and upheavals in Eastern Europe. The new antieurocentrism expresses itself in the interest in the early histories of nonEuropean peoples who for too long have been eclipsed by the search for European civilization's roots (the Middle East, Greece, Rome). The frame of reference for South African history is no longer European colonization, but the African continent. A curriculum on such a scale is not without risks, of course: first and foremost, it is not unthinkable that these great expectations may never be realized. In practice, the project of an allembracing World History where all civilizations have equal representation is barely feasible. And furthermore, it is doubtful whether one can escape from a Eurocentric perspective. There is simply no way for the specified aims of the new national image of history to ignore the fact that the frame of reference, namely the South African nation, is the product of European intervention and not of African traditions. One does of course not change anything in the frame of reference by replacing the 'culprits' with the 'victims'. Can it be coincidence that one of the brochures on the history of the ANC begins with the statement that, 'in 1652, the Dutch set foot on South African soil?? ${ }^{47}$

'The Need to be Fair, Accurate and Inclusive', could be the creed of the new South African historiography. To summarize, it boils down to a global endeavour to create a national image of history which is as integrated and as 'inclusive' as possible. ${ }^{48}$ The new government's drive to 'nationalize' South Africa's past also explains why present-day history pedagogues are averse to any suggestion of introducing separate textbooks in the education departments of the different provinces. In that way all population groups will not always have an equally strong representation. Government is particularly apprehensive that Afrikaner nationalists will keep the old

46 A Grundlingh, 'Some Trends in South African Academic History: Changing Contexts and Challenges' in Towards New Histories for South Africa, pp. 196-213.

47 Mzabalazo. A Pictural History of the African National Congress (Belleville: The Mayibuye Centre, 1994) 1.

48 This can also be seen in institutionalized initiatives such as museums: JM Gore, 'New Histories in a Post-Colonial Society. Transformation in South African Museums since 1994' in Historia, 2005, 50(1), pp. 75-102; S Marschall, 'Making Money with Memories. The Fusion of Heritage, Tourism and Identity Formation in South Africa" in Historia, 2005, 50(1), pp. 103-122. 
image of history alive. In education, the curriculum of history can be nothing other than national.

An image of history encompassing the historical experiences of as many groups as possible thus needs to do more than reverse the old schoolbook version of the past - i.e. the roles of 'whites' and 'blacks'. ${ }^{49}$ In the new situation one would be wrong to create the impression that all Afrikaans-speaking whites were racist oppressors or that all non-whites were heroic heroes of the resistance. One notes the tendency of some to diabolize the past and to identify only with positive aspects from the 'own' history. The result is a moralizing attitude condemning the past or parts thereof. An image of history which remains dualistic in nature ('good' versus 'bad', 'white' as opposed to 'black', 'heroes' or 'villains') threatens to lead to historical amnesia. In that respect it is noteworthy that the new South African image of history no longer wishes to see itself placed within the tradition of the previous 'oppositional history'50 from the years of the anti-apartheid struggle. The latter is now seen as a necessary, onesided correction of the one-sided image of history of the apartheid regime. What is required for the $21^{\text {st }}$ century is a synthesis including all historical narratives, a mirror of the 'Rainbow Nation' in the past.

\section{Conclusion}

Anachronisms are mostly seen as major errors for the writing of history. 'Good' historiography is supposed to avoid anachronism. In practice, however, the reality is far less uncomplicated. Defenders of both the new and the old historical discourses will argue that both their adversaries commit the error of anachronism. Anachronism is not a by-product of a particular bad form of historical writing. It is an inevitable phenomenon that accompanies any attempt to rethink old methods and old paths of historical representation. A reflection on anachronism - defined as any attempt to reconstruct the historical chain of events and meanings and to adopt a new interpretive model of knowledge - intrinsically linked to any operation of rewriting history. This is the case in the use of new historiographical concepts derived from the need to promote political and ideological goals, such as the creation of 'nation building' or the promotion of a multicultural idea. It moreover applies to a new use of language that reflects contemporary cultural and political assumptions, more than historical experiences.

If we look at Lorenz' classification of anachronism, the South African case clearly fits into the second and the third category: 'anachronism of language' and 'anachronism of perspective'. ${ }^{51}$ We have argued that

$49 \mathrm{~J}$ Bam and P Visser, A New History for a New South Africa, pp. 34-37; 136-138.

50 A typical ANC interpretation of South African history can be found in: J Pampallis, Foundations of the New South Africa (Cape Town: Maskew Miller Longman, 1991).

51 C Lorenz, 248-249. 
linguistic anachronism is intrinsically linked to the political and cultural turn that has taken place in South Africa due to the fall of apartheid and the introduction of plural democracy. The dominant non-racialist ideology has created a set of discourses through which new light is being shed on the past. Language serves as the binocular through which historians can not do anything else but looking back at the past. But 'anachronism of perspective' is even more pervasive. Historians nowadays will perceive the history of their nation - often pervaded by bloodshed, conflict, and racial segregation - in view of the end of this episode. The writing of history is always a retrospective entertainment, a reflection on the past through the mirror of today. ${ }^{52}$

The 'new South Africa' is trying to project its political model of consensus onto the past. The harmony being pursued must be reflected in a common past. ${ }^{53}$ Common memory becomes the matrix for a new South African national culture. Rehabilitation for the injustice done, still remains historical rehabilitation. For the damages they suffered, people are also demanding a rightful place in history. ${ }^{54}$ Thus, historiography is more than contemplation without engagement, but always has something to do with a 'right' that may be asserted. Historiography that pursues similarly external aims, is pursuing anachronism pur sang. It should moreover be aware of the temptations of harmony, of a world without conflict. After all, it is not up to national consensus planners, pressure groups or national minorities to complete the image of history. That is up to scholarly work done by historians. The pursued broadening of the image of history is an ever recurring theme in all historiography-indevelopment. The historian will have difficulty shirking from the moral duty to constantly legitimize his scholarly activity. Each new phase in the development of historiography is legitimized as a necessary 'supplement' of the 'shortcomings' and 'gaps' of older historiography. It testifies to a finalistic approach to the practice of science, starting from the point that new insights always mean improvement when compared to what preceded. The popularization of the micro-perspective has strengthened the trend even more: now at last, 'forgotten' and 'neglected' groups get the attention they 'deserve'. It is also questionable whether the 'use of the past' will lead to better present-day conditions as well. History serves as a model of explanation to understand the present - which is anachronistic in the reverse way. Historical analogies, however, rapidly give the false

52 C Conrad and S Conrad, 'Wie vergleicht man Historiographien?, C Conrad and S Conrad (eds.), Die Nation schreiben. Geschichtswissenschaft im internationalen Vergleich (Göttingen: Vandenhoeck \& Ruprecht, 2002), p. 13.

53 S Jeppie, 'Introduction: New History?' in Toward New Histories for South Africa, pp. 118.

54 G Verbeeck, 'Pumla Gobodo-Madkizela's 'Veroverde vergeving', - in Nieuwste Tijd. Kwartaalschrift voor Eigentijdse Geschiedenis, 13, 2005, pp. 71-79. 
impression of getting a grip on a new situation. It is all too easy to believe that 'lessons can be learnt' from the past to solve today's problems. ${ }^{55}$

The German example shows that some sort of holistic unitary thinking and the projection of national consensus on the past are undesirable as far as at least one point is concerned. If that should be the case, it would (amongst other things) lead to those responsible for and the victims of National Socialism being grouped together. In the past, great difficulties arose every time efforts were made to 'normalize' German history and calls were made for reconciliation with the national past, for example at a common commemoration of 'all victims of the Second World War' ${ }^{56}$ Since the Historikerstreit, efforts have repeatedly been made to remove the partitions separating the 'perpetrators' and the 'victims', an operation stemmed every time by strong resistance. ${ }^{57}$ In Germany as well as in South Africa or any other country, it is recommended to remain wary of the temptations of a certain kind of consensus thought. ${ }^{58}$ It is desirable to keep into account the fact that the danger of such an institution is that of a new dogmatism and a new intolerance. ${ }^{59}$ As far as the South African situation is concerned, Kader Asmal, Louise Asmal and Ronald Suresh Roberts rightly affirm:

This talk of shared memory must not be understood or mystified. It is not the creation of a post-apartheid Volk or a stifling homogeneous nationhood; nor a new Fatherland. Nor is it merely a nationwide equivalent of every individual's mental ability to retain facts and arguments at the front of her consciousness. Such analogies between individual and collective memory are unhelpful. Rather, shared memory, in the intended sense, is a process of historical accountability. ${ }^{60}$

South Africa, in much respect, seems to follow the example of post-Nazi and reunified Germany. In both cases, historical thought fits into a framework of Vergangenheitsbewältigung. This means that dealing with the past is not an isolated matter, but is linked to the establishment of a democratic political culture. This leads to poetic exaggeration, as exemplified by the Caribbean poet and Nobel prize-winner Derek Walcott:

55 See my contribution to the debate on the fight against the extreme right: G Verbeeck, "Lessen uit het verleden. Historische analogie als een antifascistisch wapen?', in H de Witte (ed.), Bestrijding van racisme en rechts-extremisme. Wetenschapelijke bijdragen aan het maatschappelijk debat (Leuven - Amersfoort : ACCO, 1997) pp. 133-154. See also: G Verbeeck, 'Spoken uit het verleden. De strijd tegen het 'nieuwe fascisme"' in Krisis. Tijdschrift voor Empirische Filosofie, 2, 2003, pp. 60-75.

56 CS Maier, The Unmasterable Past. History, Holocaust and German National Identity (Cambridge - London: Harvard University Press, 1988) pp. 9-16.

$57 \mathrm{KH}$ Jarausch and M Geyer, Shattered Past. Reconstructing German Histories (Princeton - Oxford: Princeton University Press, 2003) pp. 149-172.

58 See also : G Verbeeck, 'Apartheid staat in het museum' in Nieuwste Tijd. Kwartaalschrift voor Eigentijdse Geschiedenis, 2, 2003, pp. 54-60.

59 H Adam, F van Zyl Slabbert and K Moodley, Comrades in Business. Post-Liberation Politics in South Africa (Utrecht: International Books, 1998) pp. 102-103.

$60 \mathrm{~K}$ Asmal, L Asmal and RS Roberts, Reconciliation through Truth. A Reckoning of Apartheid's Criminal Governance (Cape Town: David Phillips, 19972) pp. 9-10. 
History is fiction, subject to a fitful muse, memory. ${ }^{61}$

The writing of history has therefore more to do with imagination than with the establishment of hard facts. History is the inevitable product of historical writing. The historian's imagination - and the reader's also - is the necessary condition for the historian's work. In this sense anachronism, and the freedom to use categories, discourses, models of interpretation to model the past according to the individual wish, is inevitable. It may lead to post-modernist exaggerations, flirting with the fashionable vogue of de-constructivism. But one can agree that nations imagine being able to choose their past and therefore giving shape to their memories. ${ }^{62}$ Despite factual differences, the situation in Germany and in South Africa shows a striking resemblance here. In both countries people have an idealistic view of history, according to which knowledge of history has a purifying function. It is most entrenched in the old GDRslogan: "Aus der Geschichte lernen, heisst siegen lernen!" But a more or less comparable historical and philosophical optimism is characteristic of historical culture in the Federal Republic. Here, a dominant elite still swears by a permanent commemoration of 'Auschwitz' as a condition for democratic stability (Jürgen Habermas). National ideology in the new South Africa starts from the same axiom: "Reconciliation through Truth". ${ }^{63}$ The possibility of building a better future derives from dealing with the past. History is thus seen as a lever to greater justice. ${ }^{64}$ One can applaud this for political reasons, but at the same time one cannot but conclude that the expectations of history are particularly great. If the writing of history is intrinsically linked with a moral or political message as mentioned above, it is essentially anachronistic.

61 Quoted with consent in Ibi., p. 9.

62 A Grünenberg ed., Welche Geschichte wählen wir? (Hamburg: Rowohlt 1992), especially pp. 7-22.

63 Recent literature: JL Gibson, Overcoming Apartheid. Can Truth reconcile a Divided Nation? (Cape Town: HSRC Press, 2004); LS Graybill, Truth and Reconciliation in South Africa. Miracle or Model? (Boulder - London: Lienne Ryner Publishers, 2002).

64 G Verbeeck, 'Verzoening door herinnering? Historische cultuur in Zuid-Afrika', - in : Nieuwste Tijd. Kwartaalschrift voor Eigentijdse Geschiedenis, 3, 2001, pp. 62-76. 
